International Journal of Technology 12(1) 163-174 (2021)

Received February 2020 / Revised June 2020 / Accepted January 2021

International Journal of Technology

http://ijtech.eng.ui.ac.id

\title{
Construction of a Finned Heat Radiation Reflector for Improved Efficiency of Liquefied Petroleum Gas Stoves
}

\author{
Sudarno ${ }^{1,2^{*}}$, Sudjito Soeparman ${ }^{2}$, Slamet Wahyudi ${ }^{2}$, Agung Sugeng Widodo ${ }^{2}$ \\ ${ }^{1}$ Department of Mechanical Engineering, Faculty of Engineering, Universitas Muhammadiyah Ponorogo, Jl. \\ Budi Utomo 10 Ponorogo, East Java, 63471, Indonesia \\ ${ }^{2}$ Department of Mechanical Engineering, Faculty of Engineering, Universitas Brawijaya, Jl. Mayjend. Haryono \\ 167 Malang, East Java, 65145, Indonesia
}

\begin{abstract}
The objective in this study was to construct a finned heat radiation reflector using a cut cone-shaped stainless steel plate. In addition, its efficiency was examined by the water boiling test by varying the fin rows and angles. Measurements were performed on reflectors with one, two and three rows of fins, which were compared with conventional stoves with and finless reflectors. Furthermore, fin angles of $5^{\circ}, 10^{\circ}, 15^{\circ}, 20^{\circ}$ and $25^{\circ}$ were evaluated by the variation in the fin rows, and the most efficient configuration was investigated. Results revealed that finned reflectors increase the efficiency of liquefied petroleum gas stoves. The highest efficiency (60\%) was obtained for the reflector with three finned rows and a fin angle of $10^{\circ}$. Compared with those of conventional reflectors and reflectors without fins, $7.87 \%$ and $4.47 \%$ increase in the efficiency was observed, respectively. Furthermore, the use of finned reflectors enhanced the area of complete combustion.
\end{abstract}

Keywords: Efficiency; Fin angle; Fin rows; Finned heat reflector; LPG stove

\section{Introduction}

Low efficiency of liquefied petroleum gas (LPG) stoves is attributed to the loss of heat from the flame, which occurs due to the high-temperature difference between the flame and its surroundings caused by the distance between the head burner and load (Abdurrachim et al., 2009; Gohil and Channiwala, 2011; Syahrial, 2012; Widodo, 2014; Widodo, 2015). Therefore, this loss needs to be minimized. On the basis of the results reported in previous studies, two methods can be employed to improve the efficiency of LPG stoves: construction engineering (Dongbin et al., 2007; Pantangi et al., 2011; Khan and Saxena, 2013; Muthukumar and Shyamkumar, 2013; Wu et al., 2014; Mishra et al., 2015; Mishra and Muthukumar, 2018) and combustion optimization (Abdurrachim et al., 2009; Gohil and Channiwala, 2011; Syahrial, 2012; Widodo, 2014; Widodo, 2015; Widodo, 2016; Sudarno and Fadelan, 2016; Fadelan and Sudarno, 2017). With respect to construction engineering, one approach involves the use of brass as a head burner material and that one with a flat face design for increasing the thermal efficiency by $4 \%$ and 10\%, respectively (Pantangi et al., 2011; Khan and Saxena, 2013; Wu et al., 2014; Mishra et al., 2015; Mishra and Muthukumar, 2018).

Dongbin et al. (2007) have reported that the use of porous ceramics doped with

${ }^{*}$ Corresponding author's email: darnotec@umpo.ac.id, Tel.: +62-0352-481124; Fax: +62-0352-461796 doi: 10.14716/ijtech.v12i1.3958 
rare-earth elements leads to the change in the fire colour from red to blue. In addition, CO and $\mathrm{O}_{2}$ concentrations of blue gas decrease by $40.9 \%$ and $12.8 \%$, respectively. On the basis of other research results, the use of porous radiant burners (PRBs) leads to a $10 \%$ increase in the efficiency, with the production of more stable fire (Muthukumar and Shyamkumar, 2013). The use of a two-layer PRB in the combustion process using silicon carbon (SiC) and in the pre-heating process using alumina leads to an almost uniform radial temperature distribution. The thermal efficiency increases from $45 \%$ to $58 \%$, whereas $\mathrm{CO}$ and $\mathrm{NO}_{\mathrm{x}}$ emissions significantly decrease (Pantangi et al., 2011; Wu et al., 2014; Mishra et al., 2015). Mishra and Muthukumar (2018) have employed the same method and reported a 10.1\% increase in the thermal efficiency and a reduction in the $\mathrm{CO}$ and $\mathrm{NO}_{\mathrm{x}}$ emissions in the range of 190-410 and 4.8-21.5 ppm, respectively.

Nevertheless, limited studies on the optimization of fire utilization are available. Widodo has reported that the addition of grid material between the burner and load increases the efficiency of LPG stoves. A high efficiency of 58.8\% has been reported for a 5mm-thick grid (Widodo, 2016). Moreover, the loading height of a gas stove affects the obtained efficiency. The optimal loading height is $4 \mathrm{~mm}$, and the mass flow rate is 0.0125 L/s (Widodo, 2015). Previously, the element of embers of a nickel wire mounted between the burners and load leads to the increase in efficiency. The highest efficiency is reported for the element with a single layer of embers with a nickel diameter of $0.2 \mathrm{~mm}$ : The efficiency is enhanced by $8.32 \%$ in comparison with that of conventional LPG stoves (Sudarno and Fadelan, 2016; Fadelan and Sudarno, 2017). Furthermore, Syahrial has reported that the efficiency of biogas stoves increases by $5.6 \%$ by using perforated heat reflectors and a diameter of $10 \mathrm{~mm}$ (Syahrial, 2012). Abdurrachim et al. has reported that aluminium gas-flow collector tools increase the efficiency by $10 \%$ compared with that of conventional stoves (Abdurrachim et al., 2009). This result is in agreement with that reported by Gohil and Channiwala (2011). The use of a cover to close the combustion chamber leads to the enhanced efficiency of the gas stove. An efficiency of $66.27 \%$ is obtained at a power of $1.7849 \mathrm{~kW}$. According to Widodo (2014), the use of ceramic as a reflector material on gas stoves leads to a $2.68 \%$ enhancement in productivity, from $43.88 \%$ to $46.56 \%$.

Previous studies have concluded that the use of reflectors leads to the increase in the efficiency of LPG stoves. However, given that the reflection of radiation involves diffusion, the use of finless reflectors leads to the loss of heat to the environment (Incropera et al., 2006; Holman, 2010). Therefore, in this study, fins are added to minimize the heat loss, which cannot be controlled by finless reflectors. In this study, the objective is to determine the effect of finned heat reflectors on the efficiency increase and temperature distribution of LPG stoves.

\section{Methods}

\subsection{Research Material Specifications}

In this experiment, LPG was used because the flame stability and working region of LPG are greater than those of dimethyl ether (Anggarani et al., 2020). The experiment materials included a single-furnace LPG stove, SNI 7368-2001 or similar, an LPG tube SNI 1452 2011, PERTAMINA LPG for households (Aisyah et al., 2015), an aluminum pan, a stopwatch, a water thermometer (accuracy of $\pm 0.5^{\circ} \mathrm{C}$ ), digital scales (accuracy of $\pm 0.1 \mathrm{~g}$ ), a measuring cup, a data logger (type USB-4718, 8-ch Thermocouple Input USB Module), thermocouples (diameter of $1.6 \mathrm{~mm}$ and a maximum temperature of $1300^{\circ} \mathrm{C}$ ), a flow metre (accuracy of $\pm 0.01 \mathrm{~g}$ ), water, and a finned reflector comprising stainless steel with a height of $30 \mathrm{~mm}$ and 
an angle of $22.5^{\circ}$ was measured from the vertical axis (Sumadhijono, 2003). The width and height of the fin were $20 \mathrm{~mm}$ and $5 \mathrm{~mm}$, respectively (Figure 1a).



(a)

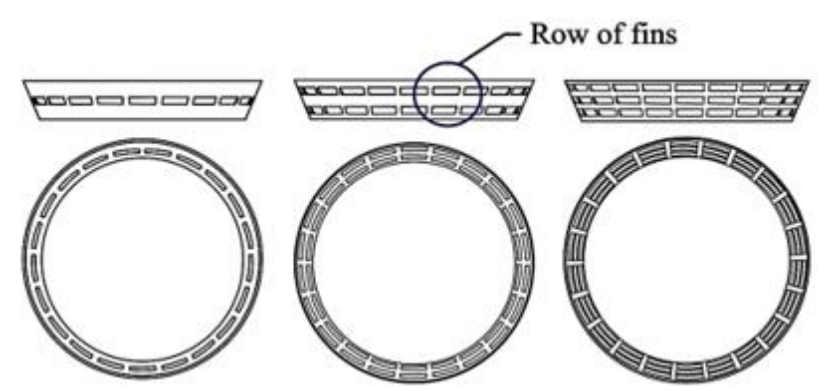

(b)

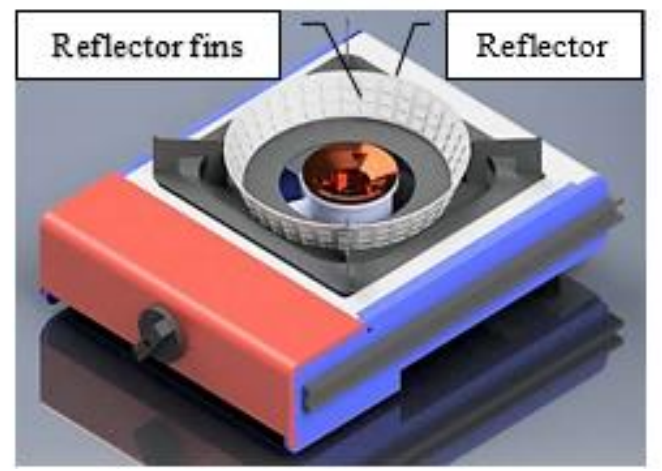

(c)

Figure 1 (a) Fin dimension; (b) finned reflector model; and (c) installation of the finned reflector on the LPG stove

The diameter of the aluminum pan was $220 \mathrm{~mm}$, and its water mass was two-thirds the volume of the pan, which is $3625 \mathrm{~g}$ (World Bank, 1985; Panigrahy et al., 2016a; Sudarno and Fadelan, 2016; Fadelan and Sudarno, 2017; Sakthivadivel and Iniyan, 2017). Reflectors with one, two and three rows of fins were used (Figure 1b). For the best measurement results, the angles of the fins were varied at $5^{\circ}, 10^{\circ}, 15^{\circ}, 20^{\circ}$ and $25^{\circ}$. Figure $1 \mathrm{c}$ shows the installation of the finned reflector on the LPG stove.

\subsection{Measurement Process}

\subsubsection{Efficiency measurement}

The water boiling test (WBT) was employed to determine the efficiency of the stove. The measurement was started by placing the pan on a stove top after the stabilization of the fire for $5 \mathrm{~min}$ from the initial ignition. Blue flame was maintained under a constant LPG gas flow rate. The LPG consumption under each treatment was maintained constant, and on the basis of the measurements, the LPG consumption rate was $0.19 \mathrm{~kg} / \mathrm{h}(0.05 \mathrm{~g} / \mathrm{s})$. This condition can be achieved due to the almost constant pressure of LPG inside the tube during the discharging process (Setiyo et al., 2017). To maintain a steady LPG flow, adjustments and controls were made on the regulator, flow meter and LPG gas valve openings on the stove. Water and ambient temperature data were recorded every $5 \mathrm{~min}$ until the water started to boil. Heating continued for $60 \mathrm{~min}$. Subsequently, the mass used and the mass of lost steam were determined. This process was repeated eight times.

\subsubsection{Measurement of fire temperature distribution}

The temperature distribution was measured on a stove with load, such as a conventional one, and with the use of reflectors with and without fins. 


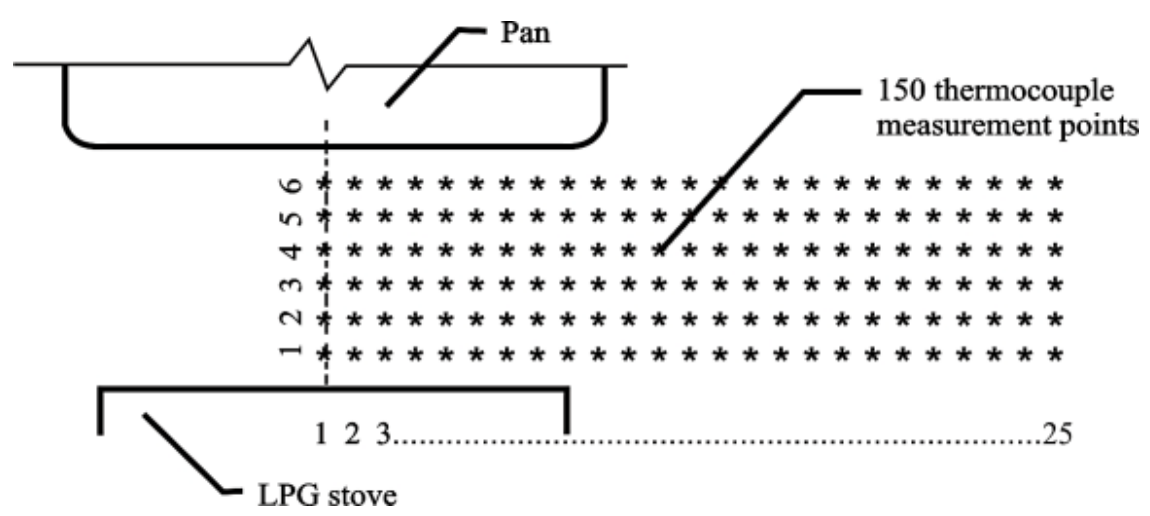

Figure 2 Installation determination position points

Measurement started from the point on the outer side using a six-channel thermocouple and shifted towards the axis at an interval of $5 \mathrm{~mm}$ until a total data of $6 \times 25$ points (150) were obtained (Figure 2). Data at each point were collected 25 times. The average temperature results were visualized to obtain the isothermal temperature distribution contour.

\section{Results and Discussion}

\subsection{Efficiency Measurement}

Stove efficiency measurements were conducted according to the Indian Standard 4246: 2002, which involved a WBT (EPA and PCIA., 2014; Panigrahy et al., 2016a; Panigrahy and Mishra, 2016b; Ziapour et al., 2016; Sakthivadivel and Iniyan, 2017). WBT was conducted by heating the water until it reached the boiling temperature, and the process continued up to $60 \mathrm{~min}$. The stove efficiency was numerically calculated by the following equations (EPA and PCIA., 2014; Panigrahy et al., 2016a; Sakthivadivel and Iniyan, 2017):

$$
\begin{gathered}
\eta=\frac{\Delta E_{H_{2} O, \text { heat }}+\Delta E_{H_{2} O, \text { evap }}}{E_{\text {released }}} \\
\Delta E_{H_{2} O, \text { heat }}=m_{w} \cdot C_{p w}\left(T_{w f}-T_{w i}\right) \\
\Delta E_{H_{2} O, \text { heat }}=C_{p w}\left(m_{w i}-m_{p}\right)\left(T_{w f}-T_{w i}\right) \\
\Delta E_{H_{2} O, \text { evap }}=m_{u} \cdot H_{u} \\
E_{\text {released }}=m_{f} \cdot E_{L P G} \\
\eta=\frac{\left\{\left(m_{w i}-m_{p}\right) C_{p w}\left(T_{w f}-T_{w i}\right)+m_{u} \cdot H_{u}\right\}}{m_{f} \cdot E_{L P G}}
\end{gathered}
$$

where $\eta(\%)$ is the stove efficiency; $\Delta E_{\mathrm{H}_{2} \mathrm{O} \text {,heat }}(\mathrm{kJ})$ is the energy to heat the water; $\Delta E_{\mathrm{H}_{2} \mathrm{O} \text {,evap }}(\mathrm{kJ})$ is the energy to vaporize the water; $E_{\text {released }}(\mathrm{kJ})$ is the energy produced by the fuel; $\mathrm{m}_{\mathrm{w}}(\mathrm{kg})$ is the water mass; $C p_{w}(\mathrm{~kJ} / \mathrm{kg} \mathrm{K})$ is the specific heat capacity of water; $T w_{f}$ $(\mathrm{K})$ and $T w_{i}(\mathrm{~K})$ are the water temperatures before and after treatment, respectively, in Kelvin; $m_{w i}(\mathrm{~kg})$ is the initial mass of water and pan; $m_{p}(\mathrm{~kg})$ is the mass of the pan; $m_{u}(\mathrm{~kg})$ is the mass of steam after handling; $\mathrm{H}_{\mathrm{u}}(2260 \mathrm{~kJ} / \mathrm{kg})$ is the latent heat of vaporization (EPA and PCIA., 2014) is the latent heat of vaporization; $m_{f}(\mathrm{~kg})$ is the mass of fuel used after treatment; and $E_{\mathrm{LPG}}(47100 \mathrm{~kJ} / \mathrm{kg})$ is the net calorific value of LPG (EPA and PCIA., 2014). 


\subsubsection{Measurement of distance between burners and loads}

This measurement was conducted to determine the optimal load for the burner in conventional LPG stoves. Figure 3 shows the graph of the measurement results.

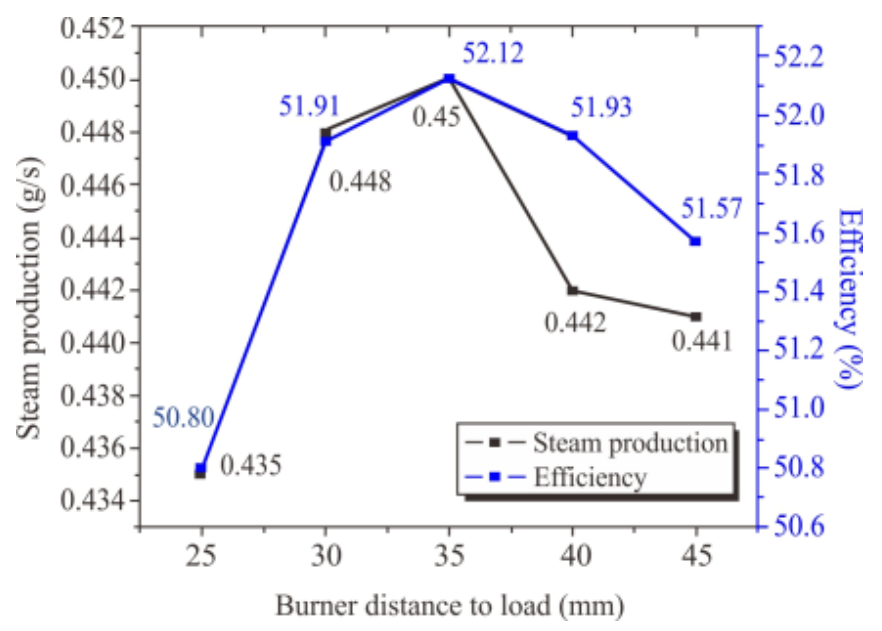

Figure 3 Graph of measurements results of the distance burner with a load in conventional LPG stoves

The distance between the burner with a load of $35 \mathrm{~mm}$ afforded the highest efficiency of $52.12 \%$, because at that distance, an optimal balance occurred between the secondary air supply and fuel consumption. In addition, the balance made the process of mixing air and fuel more homogeneous. The optimal distance between the burner and load was used as a reference for measuring the efficiency and temperature distribution.

\subsubsection{Measurements by the variation of fin rows in the reflector}

On the basis of Figure 4a, steam production continuously increased with the increased addition of fin rows.
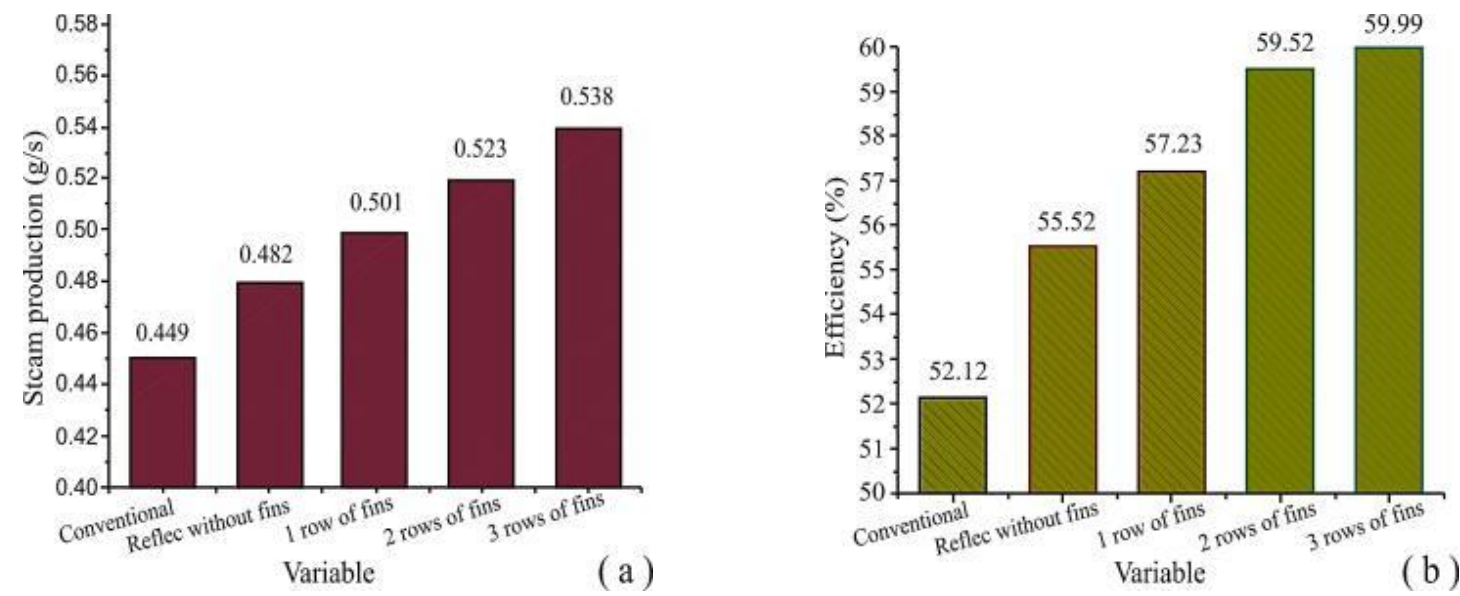

Figure 4 Measurement results for the variation of fin rows in the reflector: (a) steam production; and (b) efficiency

With the use of reflectors, the efficiency increased (Figure 4b), with the highest efficiency observed for three-row finned reflectors (Gohil and Channiwala, 2011). This condition leads to the increased area of complete combustion and intensifies the heat absorbed by the load, leading to increased steam production. Compared with stoves without-finned reflectors, in conventional stoves, a steam production increase of $0.033 \mathrm{~g} / \mathrm{s}$ was observed, in addition to a $3.39 \%$ positive deviation in efficiency. This result was 
attributed to the use of finless reflectors, which capture and reflect heat loss to the environment (Gohil and Channiwala, 2011; Ziapour et al., 2016).

Compared with reflectors with one row of one fin, in finless reflectors, steam production increased by $0.019 \mathrm{~g} / \mathrm{s}$, which in turn improved the efficiency by $1.71 \%$. Compared with reflectors with two rows, in one-row fin reflectors, the steam production significantly increased $(0.022 \mathrm{~g} / \mathrm{s})$, thereby increasing the efficiency by $2.29 \%$. The highest efficiency was observed for a three-row finned reflector, with a $7.87 \%$ and $4.47 \%$ increase compared with those in conventional stoves and reflectors without fins, respectively. In addition, the average measurement error was calculated to be $0.69 \%$. Our results are in accordance with the radiation properties in with the radiation is reflected by a reflective surface (Incropera et al., 2006; Holman, 2010). As the material surface in this study is not perfectly smooth, heat radiation is diffusely reflected (Incropera et al., 2006; Holman, 2010). With the use of fins, radiation heat losses are captured and reflected more optimally. As a result of heat reflection, the unburned fuel steam in the chamber burns. With the enhancement in the process efficiency, complete combustion is improved, as well as the heat transferred to the load. In addition, the results obtained herein were in agreement with those reported previously: The use of reflectors can increase the efficiency of stoves (Abdurrachim et al., 2009; Gohil and Channiwala, 2011; Syahrial, 2012).

\subsubsection{Measurements by variation of fin angle in the reflector}

The inclination angle of reflectors affects their ability to collect and reflect radiation (Anggarani et al., 2020). In these experiments, the fin angle affected steam production (Figure 5). The total steam production was affected by heat from the combustion; the greater this is, the more efficient the process.

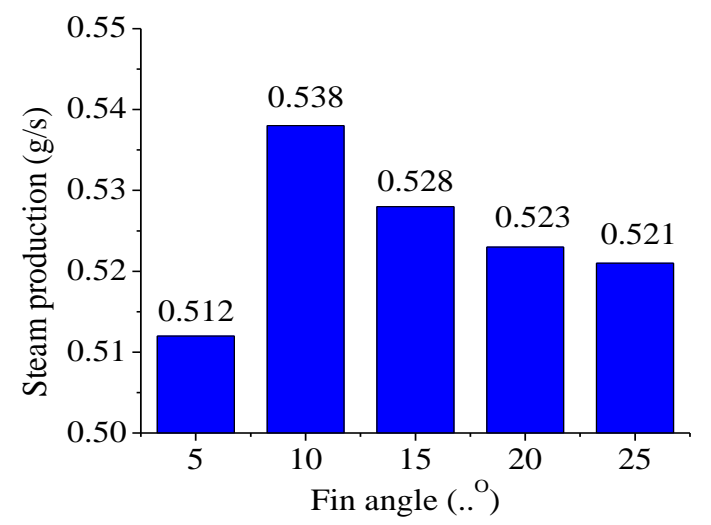

(a)

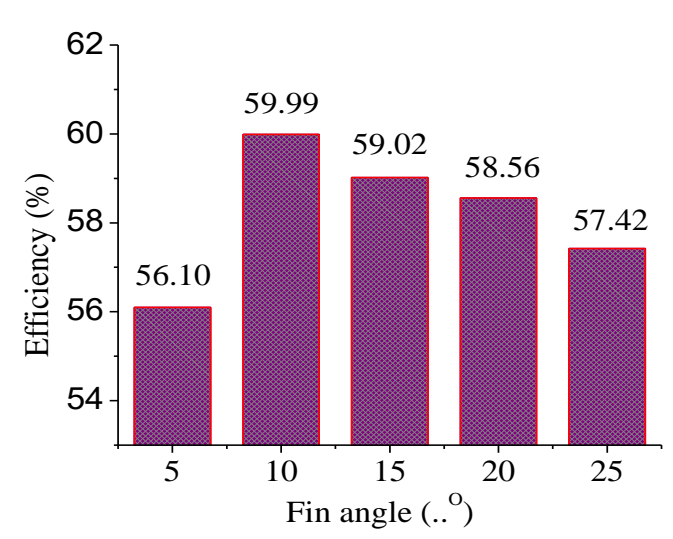

(b)

Figure 5 Measurement results for the variation of the fin angle in the reflector: (a) steam production and (b) efficiency

The highest steam production of $0.538 \mathrm{~g} / \mathrm{s}$ was observed at a fin angle of $10^{\circ}$, while the lowest steam production of $0.512 \mathrm{~g} / \mathrm{s}$ was observed at a fin angle of $5^{\circ}$. By the comparison of fin angles of $5^{\circ}-10^{\circ}$, steam production increased by $0.026 \mathrm{~g} / \mathrm{s}$, from 0.512 to $0.538 \mathrm{~g} / \mathrm{s}$. Hence, the efficiency increases by $3.89 \%$ (from $56.10 \%$ to $59.99 \%$ ). At a fin angle of $10^{\circ}$, the secondary air requirement for the combustion process was well fulfilled to complete the combustion. When complete combustion occurs, an increased amount of steam is produced via the increase in the heat area and temperature, which are related to efficiency improvement. In addition, the heat loss from the flame to the environment through the gap under the fins was minimal, thereby making the function of the reflector more optimal for thermal reflection. The highest efficiency of $59.99 \%$ was obtained in our experiment using 
a stove with three finned rows and an angle of $10^{\circ}$. This efficiency is $6.57 \%$ greater than that reported in the study by Syahrial, in which a perforated reflector with a diameter of 10 $\mathrm{mm}$ is used (Syahrial, 2012). This obtained efficiency is also better than that reported in the study by Widodo by $13.44 \%$, in which ceramics is used as the reflector material (Widodo, 2014).

At fin angles of $10^{\circ}$ to $15^{\circ}$, the production decreased by $0.010 \mathrm{~g} / \mathrm{s}$, from 0.538 to 0.528 $\mathrm{g} / \mathrm{s}$. This resulted in a $0.96 \%$ decrease in the efficiency, from $59.99 \%$ to $59.02 \%$. This decrease was attributed to a fin angle of $15^{\circ}$, where the gap under the fins was extremely wide, indicative of the increase of heat loss to the environment and subsequently leading to the less optimal function of the reflector; hence, efficiency decreases. Similar alterations were observed at fin angles of $20^{\circ}$ and $25^{\circ}$; the greater the fin gap, the higher the heat loss to the environment. At fin angles of $15^{\circ}$ to $20^{\circ}$, steam production decreased by $0.005 \mathrm{~g} / \mathrm{s}$, from 0.528 to $0.523 \mathrm{~g} / \mathrm{s}$. This resulted in the slight decrease in the efficiency from $59.02 \%$ to $58.56 \%$. The same result was observed at angles of $20^{\circ}$ and $25^{\circ}$, with the $1.13 \%$ decrease in the efficiency, from $58.56 \%$ to $57.42 \%$. In these measurements, an average error of $0.43 \%$ was obtained. A fin angle of $10^{\circ}$ afforded the highest amount of steam, leading to the highest efficiency (Figure 5). This result was attributed to the angle at which the reflector functions optimally, as well as the adequate fulfillment of the secondary air, also referred to overfire air, requirements for the combustion process.

\subsection{Measurement of LPG Stove Temperature Distribution}

This measurement aimed to determine the effect of the installed finned heat reflector on the temperature distribution contour of isothermal fire. Matlab R2010a was employed to create visualization of the temperature distribution data. By utilizing this visualization, the effectiveness of the finned heat reflector can be concluded.

\subsubsection{Fire temperature distribution by the variation of fin rows in the reflector}

In this measurement, the stove was loaded, and finned heat reflectors were installed. Figure 6 shows the results of the fire temperature distribution.

The lowest and highest temperatures were $79^{\circ} \mathrm{C}$ and $1084^{\circ} \mathrm{C}$, respectively (Figure 6a). In addition, conventional stoves exhibited a relatively low average hotness with relatively low temperature distribution areas. This result was related to the convection from the flame to the surrounding area, leading to a low production efficiency (Gohil and Channiwala, 2011). By using a finless reflector, the lowest recorded temperature was $78^{\circ} \mathrm{C}$; this temperature is $1.2^{\circ} \mathrm{C}$ less than that observed in a conventional stove, and the highest temperature was $1107^{\circ} \mathrm{C}$, which was $22.6^{\circ} \mathrm{C}$ greater than that observed in a conventional stove. From these figures, the areas of extreme temperatures greater than $1000^{\circ} \mathrm{C}$ and between $900^{\circ} \mathrm{C}$ and $1000^{\circ} \mathrm{C}$ were considerably wider than those observed in conventional stoves. This result is related to the capture of wasted heat by the reflector and subsequent reflection of the area of combustion and load (Widodo, 2018).

By using a single-row fin reflector, the lowest temperature was $78^{\circ} \mathrm{C}$, corresponding to $0.2^{\circ} \mathrm{C}$ greater than that with a finless reflector, and the maximum temperature was $1115^{\circ} \mathrm{C}$, or $7.5^{\circ} \mathrm{C}$ higher than that with a finless reflector. The main difference was in the area with a high temperature greater than $1000^{\circ} \mathrm{C}$ and between $900^{\circ} \mathrm{C}$ and $1000^{\circ} \mathrm{C}$, which was wider than that with the finless reflector. Compared to finless reflectors, in reflectors with fins, wasted heat can be captured. Moreover, the gap under the fins is beneficial for secondary air supply, maintaining a balance between air requirements and LPG consumption. With a two-row fin reflector, the lowest temperature was $77^{\circ} \mathrm{C}$, corresponding to $1^{\circ} \mathrm{C}$ less than that with a single row, and the highest temperature was $1131^{\circ} \mathrm{C}$, corresponding to $16^{\circ} \mathrm{C}$ higher than that with a single row (Figure 6d). 


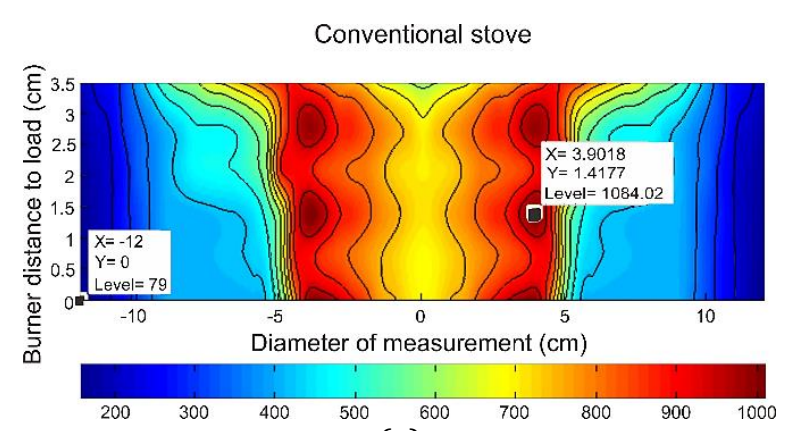

(a)

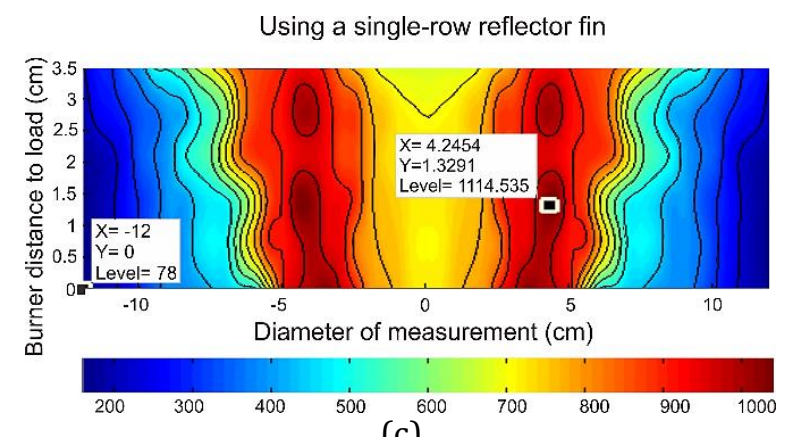

(c)

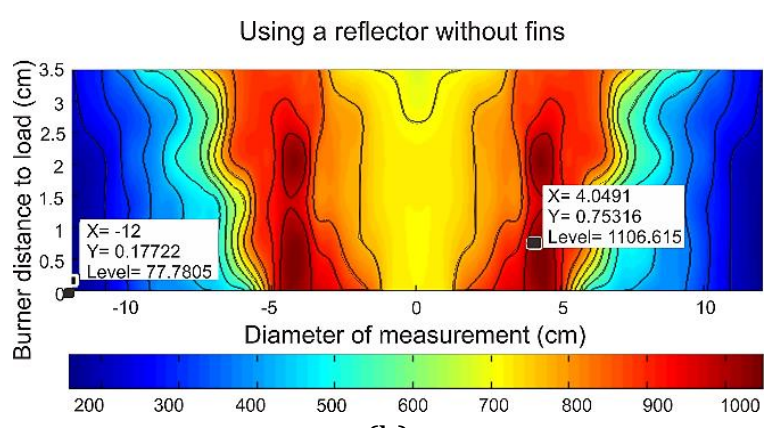

(b)

Using a two-row reflector fin

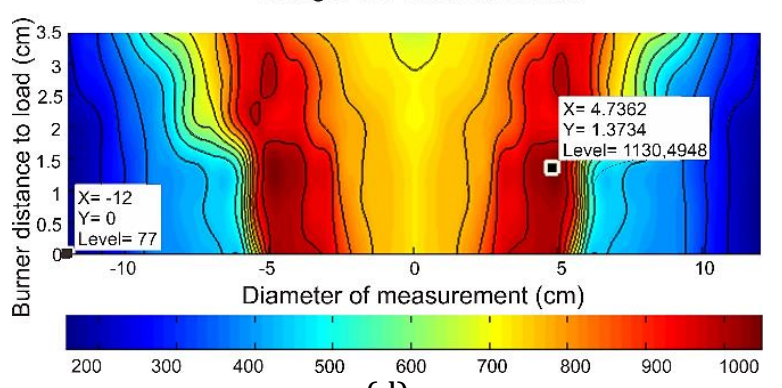

(d)

Using a three-row reflector fin

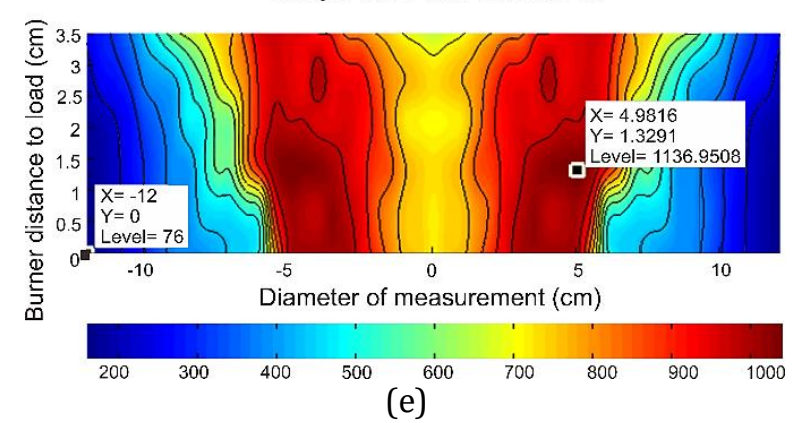

Figure 6 Temperature distribution of the LPG stove fire: (a) conventional; (b) using a finless reflector; (c) using a single-row reflector fin; (d) using a two-row reflector fin; and (e) using a three-row reflector fin

Furthermore, the area of high temperature greater than $1000^{\circ} \mathrm{C}$ and between $900^{\circ} \mathrm{C}$ and $1000^{\circ} \mathrm{C}$ was wider, whereas that between $800^{\circ} \mathrm{C}$ and $900^{\circ} \mathrm{C}$ was relatively less than that with one row of fins. These conditions were observed due to the increase in the function of the reflector, minimizing heat loss to the environment.

In the case of the three-row finned reflector, the lowest temperature was $76^{\circ} \mathrm{C}$, corresponding to $1^{\circ} \mathrm{C}$ less than that of the two-row reflector, and the highest temperature was $1137^{\circ} \mathrm{C}$, corresponding to $6.5^{\circ} \mathrm{C}$ higher. The most noticeable difference was observed in the area of high temperature greater than $1000^{\circ} \mathrm{C}$. Between $900^{\circ} \mathrm{C}$ and $1000^{\circ} \mathrm{C}$, it was considerably wider than that of the two-row fin reflector. The increase occurred due to more complete combustion, and the reflector function was optimal by the addition of the number of rows of fins.

\subsubsection{Fire temperature distribution by the variation of fin angle in the reflector}

On the basis of Figures $4 \mathrm{~b}$ and $6 \mathrm{e}$, compared to the other variations, the reflector with three rows of fins exhibited the highest efficiency and the largest area of high temperature. According to these results, a heat radiation reflector was selected with three rows of fins for the temperature distribution measurement by the variation in the fin angle on the reflector. Figure 7 shows the measurement results. 


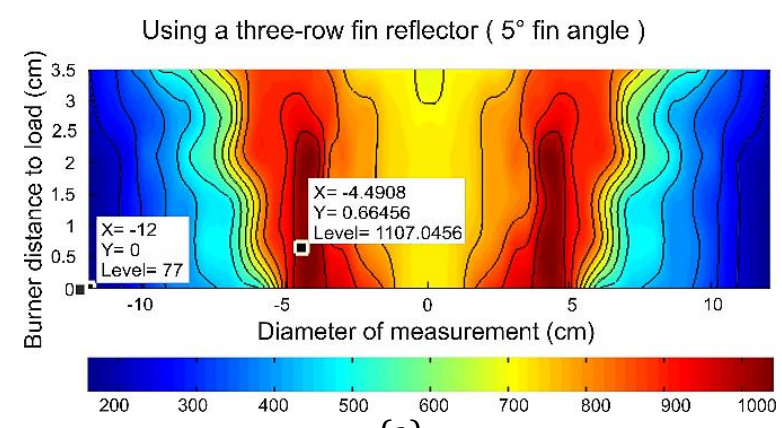

(a)

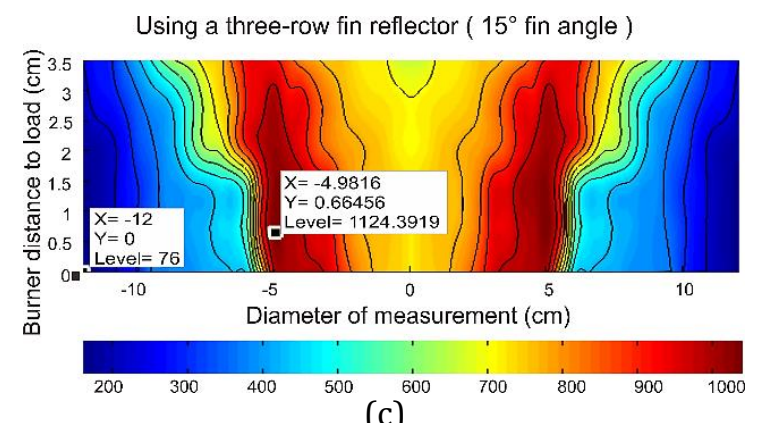

(c)

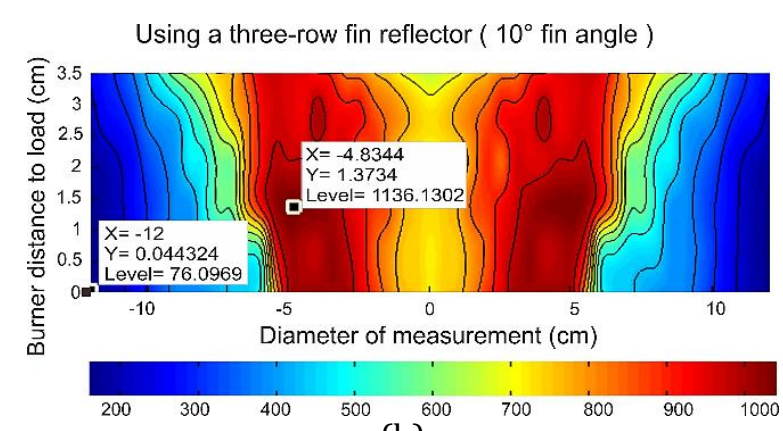

(b)

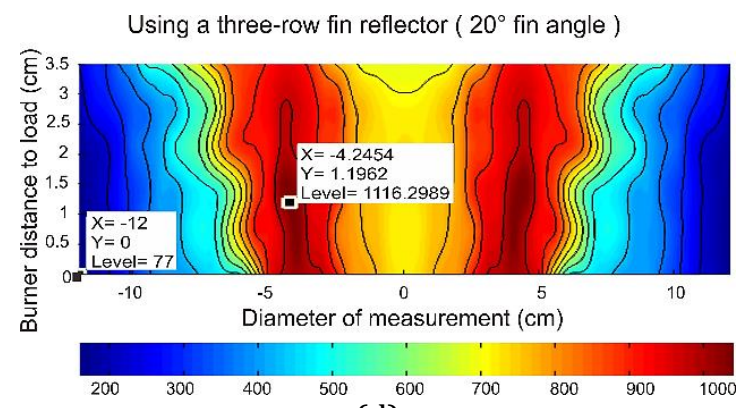

(d)

Using a three-row fin reflector ( $25^{\circ}$ fin angle )

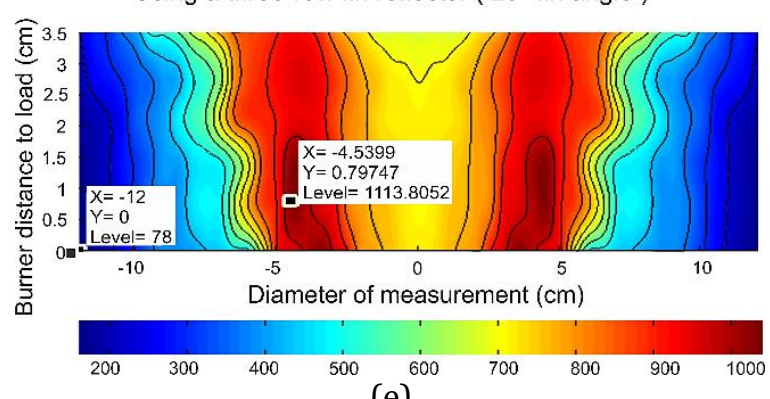

(e)

Figure 7 LPG stove temperature distribution using a reflector with three rows of fins at angles of: (a) $5^{\circ}$; (b) $10^{\circ}$; (c) $15^{\circ}$; (d) $20^{\circ}$; and (e) $25^{\circ}$

The lowest and highest temperatures were $77^{\circ} \mathrm{C}$ and $1107^{\circ} \mathrm{C}$, respectively (Figure $7 \mathrm{a}$ ). A fin angle of $5^{\circ}$ produced an area of high temperature of greater than $1000^{\circ} \mathrm{C}$, which was relatively small. However, at temperatures between $900^{\circ} \mathrm{C}$ and $1000^{\circ} \mathrm{C}$, the area was quite wide, and the most extensive range was between $77^{\circ} \mathrm{C}$ and $900^{\circ} \mathrm{C}$. As radiation reflection occurred by diffusion, with a fin angle of $5^{\circ} \mathrm{C}$, substantial heat loss was still observed (Menghini et al., 2008).

The lowest temperature was $76^{\circ} \mathrm{C}$, corresponding to $1^{\circ} \mathrm{C}$ lower, and the highest temperature was $1137^{\circ} \mathrm{C}$, or $29.9^{\circ} \mathrm{C}$ greater than that with a fin angle of $5^{\circ}$. The main difference was observed in the high-temperature area of greater than $1000^{\circ} \mathrm{C}$ and between $900^{\circ} \mathrm{C}$ and $1000^{\circ} \mathrm{C}$, which was considerably wider than that with a fin angle of $5^{\circ}$. The increase in the high-temperature area occurred due to complete combustion. The function of the reflector was increasingly optimal at a fin angle of $10^{\circ}$. Complete combustion was caused by the achievement of a secondary air supply flowing through the gap under the fins. The lowest temperature of $76^{\circ} \mathrm{C}$ was relatively similar with that of a fin angle of $10^{\circ}$, and the highest temperature was $1124^{\circ} \mathrm{C}$, which was $11.7^{\circ} \mathrm{C}$ less than that with a fin angle of $10^{\circ}$ (Figure 7c). In addition, the area of high temperature of greater than $1000^{\circ} \mathrm{C}$ and between 900 and $1000^{\circ} \mathrm{C}$ was less than that with a fin angle of $10^{\circ}$. The reflector was not optimal due to the large gap under the fins, and diffused heat radiation was lost to the surrounding area (Menghini et al., 2008; Gohil and Channiwala, 2011). 
The lowest temperature was $77^{\circ} \mathrm{C}$, which was $1^{\circ} \mathrm{C}$ higher, and the highest temperature was $1116^{\circ} \mathrm{C}$, which was $8.1^{\circ} \mathrm{C}$ less than that with a fin angle of $15^{\circ}$ (Figure $7 \mathrm{~d}$ ). Moreover, the area of high temperature of greater than $1000^{\circ} \mathrm{C}$ was smaller, but between $900^{\circ} \mathrm{C}$ and $1000^{\circ} \mathrm{C}$, the area was slightly wider than that with an angle of $15^{\circ}$. The lowest temperature was $78^{\circ} \mathrm{C}$, which was $1^{\circ} \mathrm{C}$ higher, and the highest temperature was $1114^{\circ} \mathrm{C}$, which was $2.5^{\circ} \mathrm{C}$ less than that with a fin angle of $20^{\circ}$. In addition, the area of high temperature of greater than $1000^{\circ} \mathrm{C}$ was smaller, although between $800^{\circ} \mathrm{C}$ and $1000^{\circ} \mathrm{C}$, it was relatively similar to that with a fin angle of $20^{\circ}$. The problem at fin angles of $20^{\circ}$ and $25^{\circ}$ was the same as those at a fin angle of $15^{\circ}$; the greater the angle of the fin, the lower the function of the reflector. The presence of large gaps under the fins makes heat loss into the environment even greater.

\section{Conclusions}

The use of finned heat radiation reflectors in LPG stoves positively affects efficiency. Reflectors with one row of fins exhibited an efficiency of $57.23 \%$, representing $5.11 \%$ and $1.71 \%$ increase compared with those of conventional stoves and stoves with finless reflectors, respectively. However, reflectors with two rows of fins exhibited an efficiency of $59.52 \%$, representing $7.40 \%$ and $4.00 \%$ increase in comparison with conventional stoves and stoves with finless reflectors, respectively. The highest efficiency (60\%) was observed for the reflector with three rows of fins or $7.87 \%$ and $4.47 \%$ increase compared to conventional and finless stoves. This efficiency is greater than that reported in the study by Syahrial (by 6.57\%) and by Widodo (by 13.44\%), in which a perforated reflector with a diameter of $10 \mathrm{~mm}$ and ceramics as the reflector material are used, respectively. On the basis of the contour of the isothermal temperature distribution, the use of finned heat radiation reflectors increases the area of complete combustion, thereby increasing the heat absorption by the load and improving steam production; hence, efficiency is enhanced.

\section{Acknowledgements}

This study was supported by a Doctoral Research Grant from the Ministry for Research and Technology Higher Education of Indonesia, with contract No. 037/SP2H/LT/K7/KM/2018. The authors would like to thank Prof. Dr. Eng. Mikrajuddin Abdullah from the Bandung Institute of Technology, Indonesia; Rizal Arifin, M.Si., Ph.D. from the Muhammadiyah University of Ponorogo, Indonesia; and Dr. Muji Setiyo, S.T., M.T. from the Muhammadiyah University of Magelang, Indonesia.

\section{References}

Abdurrachim, A., Wardani, D., Yudi, T., 2009. Fuel Saver on Household Gas Stoves. Jurnal Teknik Mesin, Volume 24(1), pp. 57-66

Aisyah, L., Rulianto, D., Wibowo, C.S., 2015. Analysis of the Effect of Preheating System to Improve Efficiency in LPG-fuelled Small Industrial Burner. Energy Procedia, Volume 65, pp. 180-185

Anggarani, R., Aisyah, L., Wibowo, C.S., Nugroho, Y.S., Dhiputra, I.M.K., 2020. Experimental Comparison of Working Region, Flame Stability, and Flame Height of LPG, DME, and DME-mixed LPG in an Atmospheric Diffusion Cylindrical Burner. International Journal of Technology, Volume 11(2), pp. 400-410

Dongbin, Z., Jinsheng, L., Guangchuan, L., Yan, D., Gang, X., 2007. Effects on Combustion of Liquefied Petroleum Gas of Porous Ceramic Doped with Rare Earth Elements. Journal of Rare Earths, Volume 25, pp. 212-215 
EPA \& PCIA, A., 2014. The Water Boiling Test, 4.2.3 (March), p. 86. Available Online at: http://www.cleancookstoves.org/our-work/standards-and-testing/learn-abouttesting-protocols/, Accessed on April 12, 2018

Fadelan, F., Sudarno, S., 2017. Effect of Diameter of Embers on the Improvement of Efficiency of LPG Stove. Jurnal Ilmiah Semesta Teknika, Volume 20(2), pp. 154-163

Gohil, P.P., Channiwala, S.A., 2011. Experimental Investigation of Performance of Conventional LPG Cooking Stove. Fundamental Journal of Thermal Science and Engineering, Volume 1(1), pp. 25-34

Holman, J.P., 2010. Heat Transfer, Tenth edition, McGraw-Hill Series in Mechanical Engineering

Incropera, F.P., Dawwit, D.P., Bergman, T.L., Lavine, A.S., 2006. Fundamentals of Heat and Mass Transfer, Sixth edition, New York: John Willey \& Sons. Inc

Khan, M.Y., Saxena, A., 2013. Performance of LPG Cooking Stove using Different Design of Burner Heads. International Journal of Engineering Research \& Technology (IJERT), Volume 2(7), pp. 656-659

Menghini, D., Marra, F.S., Allouis, C., Beretta, F., 2008. Effect of Excess Air on the Optimization of Heating Appliances for Biomass Combustion. Experimental Thermal and Fluid Science, Volume 32(7), pp. 1371-1380

Mishra, N.K., Mishra, S.C., Muthukumar, P., 2015. Performance Characterization of a Medium-Scale Liquefied Petroleum Gas Cooking Stove with a Two-Layer Porous Radiant Burner. Applied Thermal Engineering, Volume 89, pp. 44-50

Mishra, N.K., Muthukumar, P., 2018. Development and Testing of Energy Efficient and Environment Friendly Porous Radiant Burner Operating on Liquefied Petroleum Gas. Applied Thermal Engineering, Volume 129, pp. 482-489

Muthukumar, P., Shyamkumar, P.I., 2013. Development of Novel Porous Radiant Burners for LPG Cooking Applications. Fuel, Volume 112, pp. 562-566

Panigrahy, S., Mishra, N.K., Mishra S.C., Muthukumar, P., 2016a. Numerical and Experimental Analyses of LPG (Liquefied Petroleum Gas) Combustion in a Domestic Cooking Stove with a Porous Radiant Burner. Energy, Volume 95, pp. 404-414

Panigrahy, S., Mishra, S.C., 2016b. Analysis of Combustion of Liquefied Petroleum Gas in a Porous Radiant Burner. International Journal of Heat and Mass Transfer, Volume 95, pp. 488-498

Pantangi, V.K., Mishra, S.C., Muthukumar, P., Reddy, R., 2011. Studies on Porous Radiant Burners for LPG (Liquefied Petroleum Gas) Cooking Applications. Energy, Volume 36(10), pp. 6074-6080

Sakthivadivel, D., Iniyan, S., 2017. Combustion Characteristics of Biomass Fuels in a Fixed Bed Micro-Gasifier Cook Stove. Journal of Mechanical Science and Technology, Volume 31(2), pp. 995-1002

Setiyo, M., Soeparman, S., Hamidi, N., Wahyudi, S., 2017. Characteristic of LPG compositions in the fuel line during the discharging process. International Journal of Technology, Volume 8 (1), pp. 114-123

Sudarno, S., Fadelan, F., 2016. The Improvement of the Efficiency of LPG Stoves Using Flames Elements. Jurnal Ilmiah Semesta Teknika, Volume 19(2), pp. 397-408

Sumadhijono, P.A., 2003. Experimental Study of Wasting Heat on Multiple Axis Stoves by Using a Heat Reflector. Jurnal Profesi Teknik Mesin, Volume 1(1), pp. 45

Syahrial, M., 2012. High Efficiency Biogas-Stove Fuel Performance by Adding Reflectors. Available Online at: http://digilib.its.ac.id/public/ITS-paper-19789-2109106028Presentation.pdf, Accessed on April 12, 2018 
Widodo, A.S., 2015. Optimum Pan Distance against Sheath on Water Heating System Efficiency. Jurnal Rekayasa Mesin, Volume 6(1), pp. 69-73

Widodo, A.S., 2016. Improvement of Heating System Efficiency by Adding Grid to Perforated Burner. Jurnal Rekayasa Mesin, Volume 7(1), pp. 21-25

Widodo, A.S., 2014. Radiation Sheath for Efficient Use of Energy in Gas Stoves. Jurnal Rekayasa Mesin, Volume 5(3), pp. 291-295

Widodo, A.S., 2018. The Application of Ceramic Stove Cover and Loading Distance to the Performance of Water Boiling System. In: MATEC Web of Conferences, the $2^{\text {nd }}$ International Conference on Engineering and Technology for Sustainable Development (ICET4SD 2017), 154, pp. 1-5

World Bank, E.D., 1985. Test Results on Kerosene and Others Stoves for Developing Countries. Available Online at: http://documents.worldbank.org/curated/en/647871492128395293/, Accessed on April 30, 2018

Wu, C.Y., Chen, K.H., Yang, S.Y., 2014. Experimental Study of Porous Metal Burners for Domestic Stove Applications. Energy Conversion and Management, Volume 77, pp. 380388

Ziapour, B.M., Palideh, V., Mokhtari, F., 2016. Performance Improvement of the Finned Passive PVT System using Reflectors Like Removable Insulation Covers. Applied Thermal Engineering, Volume 94, pp. 341-349 